\title{
口腔粘膜上皮内癌の臨床的研究
}

\author{
天笠光焳・桠尾想蒵子・絬 城勝彦

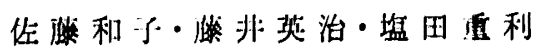

\section{Clinical study of carcinoma in situ of the oral mucosa}

\author{
Teruo Amagasa = Emiko Yokoo - Katsuhiko YũKI \\ Kazuko SATó - Eiji Fujn • Shigetoshi SurodA
}

\section{I. 緒}

口腔癌の治撩成䌙を向上させるためには，早期竝断が きわめて重要である。しかし，口腔癌の早期病变とされ る上皮内癌に関与る報告は少なく1 7)，特飞上皮内瘦の 臨床像，治療法打よび予後などについては明らかでない ところが多い，今回，われわれは口腔粘膜上皮内癌の臨 朱像を中心に，各種臨床所見，治療成積，経過転㷌，本 症の誘因扰よび前癌病变との関速などについて顿討を加 えたので，報告する。

\section{II. 対象および診断基準}

刘象拝例は昭利139年より54年むでの16年間に当科にお。 いて, 口腔粘膜上皮内澏と診断された11例である（5ち 4 例は紅色肥厚症として，すでに報告されている なお赖口蓋は, UICC 分類では中咽頭に属するが ${ }^{99}$ ，本 研究では対象症例に含めた。

上皮内癌の診断基準は，手術材料あるいは尘娭材料の 病理組織学的検索により, 異型上皮細胞が上皮全層, あ るいは上皮のほとんど全層に及んでおり，粘膜下層への 浸潤を認めないものとした. 生検材料では特に病変の中 央部を含み，大きく切除されたもののみを対象とし，採 取片の小さなもの, 臨床的に浸潤癌の辺縁より採取され たと思われるものは除外した。 な拉，白斑性病変の一部 に上皮内癌の所見を呈したものむ対像として加えた。

\section{III. 臨 床 所 見}

\section{1. 性, 年齢 (表 1)}

性別は男性 6 例, 女性 5 例, 年齢は29歳より74藏まて

東京医科菌科大学菌学部第 1 口腔外科学教室（主 任：塩田重利教授）

The First Department of Oral Surgery, Faculty of Dentistry, Tokyo Medical and Dental University (Chief: Prof. Shigetoshi Shioda)

受付日：昭和55年 10 月 3 日

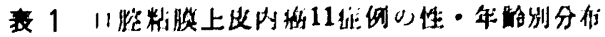

\begin{tabular}{|c|c|c|c|}
\hline 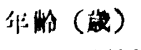 & 紧性 & 女 性 & 竍 \\
\hline $20 \sim$ & & 1 & 1 \\
\hline $30 \sim$ & 1 & & 1 \\
\hline $40 \sim$ & & 1 & 1 \\
\hline $50 \sim$ & 1 & & 1 \\
\hline $60 \sim$ & 3 & 2 & 5 \\
\hline $70 \sim$ & 1 & 1 & 2 \\
\hline 垶 & 6 & 5 & 11 \\
\hline
\end{tabular}

みられ，年代別には60歳代か 5 例，45\%を占め，70藏代 が 2 例, その活か 20 歳代から50藏代まで各 1 例であっ た.

2. 部位, 臨床型（表 2-a， b，3）

病变の主たる部位について分頪すると，舌 6 例 (55 $\%$ ，㰞口蓋，橉肉各 2 例，口底 1 例であった。

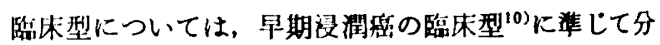
類したところ，白斑型（因 1-a， b)，杠斑型（四 2-

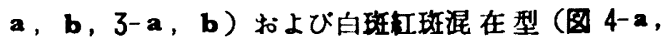

b )の 3 型が認められた。臨床型別頛度は杜斑型が 7 例 (64\%) と多く，白斑紅斑混在型㧍よび白斑型は各 2 例 であった。

臨床型と部位との関連では，紅斑型は各部位にみられ

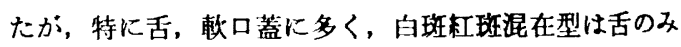
に恋められた。

3. 病変の大きさ, 境界, 硬さ, 痤痛（表 2-a，4）

病変の大きさは最小 $5 \mathrm{~mm}$ より最大 $55 \mathrm{~mm}$ までみら れ，大きさに一定の傾向なく，広く分布していた，大き さと臨床型との関連については，紅型は小さなものか ら大きなるのまでみられたが，20 mm を越える大きな 病変か７例中 5 例を占めていた。 また，白斑紅斑混在型 の 2 例は大きく, $30 \mathrm{~mm}$ を越えていたか，白斑型の 2 例は $20 \mathrm{~mm}$ よりも小さかった（表 2-a，4）。ささと 部位については，軟口蓋と舌では病変は大きく，歯肉で は $10 \mathrm{~mm}$ 以下と小さかった（表 2-a).

境界については, 白斑型と, 紅斑型の 7 例中 6 例は明 
衰 2-a 政床所少（1

\begin{tabular}{|c|c|c|c|c|c|c|c|c|c|c|c|c|}
\hline 症例 & \multicolumn{2}{|c|}{ 性・年解 } & 部 位 & \multicolumn{2}{|c|}{ 卧床像 } & 大きさ* & 境 留 & 仙 き & 将 & 痛 & 初然症状 & 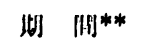 \\
\hline 1 & 男 & 74 & 舌 & 白 & 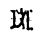 & $18 \times 11$ & 明 $\| x^{*}$ & 广中似 & 梢 & $\eta$ & 刺湤师 & 2 仆: \\
\hline 2 & 女 & 65 & 下类肉 & 白 & 轧: & $10 \times 5$ & 明 $\|$ 敫 & - & 佂 & L & 粗進恕 & 1 年 \\
\hline 3 & 男 & 35 & 舌 & \multicolumn{2}{|c|}{ 白琟紅攻 } & $45 \times 15$ & 个明㹸 & 改 & 仿 & $\eta$ & 制湤涪 & 7 か子 \\
\hline 4 & 女 & 43 & 舌 & \multicolumn{2}{|c|}{ 白玟紅功 } & $35 \times 10$ & 个明的 & 惯 & 仿 & $\eta$ & 籼湤痛 & 5 作 \\
\hline 5 & 男 & 65 & 舌 & 紅 & 城 & $20 \times 7$ & 明 & 椺 & 有 & $\eta$ & 籼漖济 & 9 か月 \\
\hline 6 & 男 & 67 & 㳄口蓝 & 紅 & 斑 & $55 \times 40$ & 明 栋 & 性 & 仿 & $\eta$ & 制激做 & 1 年 6 か月 \\
\hline 7 & 男 & 58 & 㳄口敬 & 轪 & 泡 & $42 \times 30$ & 明 & 軟 & 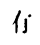 & $\eta$ & 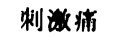 & 3 週 \\
\hline 8 & 男 & 66 & 下畨肉 & 紅 & 㳩 & $5 \times 3$ & 明 & 一 & 仿 & $\eta$ & 制湤痛 & 6 か月 \\
\hline 9 & 女 & 29 & 舌 & 紅 & 玟 & $35 \times 30$ & 明 & 制 & 仿 & $\eta$ & 刺激痛 & 5 か月 \\
\hline 10 & 女 & 65 & 舌 & 紅 & 斑 & $30 \times 20$ & 明 此 & 坏 & 佇 & $\eta$ & 剌数痽 & 1 年 5 か月 \\
\hline 11 & 女 & 71 & 口底 & 紅 & 攻 & $30 \times 15$ & 不明㙞 & 软 & 有 & $\eta$ & 刺激痛 & 1 か月 \\
\hline
\end{tabular}

*単位は mm, **症状発佂より会断までの断間

表 2-b 臨床所見（II）

\begin{tabular}{|c|c|c|c|c|c|c|}
\hline 症侧 & \multicolumn{2}{|c|}{ 科的刺激因子 } & 耎喓（期間） & 既往症 & 処 & 直*（時期） \\
\hline 1 & 義茵 & （ 2 年） & 20 本/日（50年） & - & & - \\
\hline 2 & 義茵 & （1 年） & - & - & & - \\
\hline 3 & 解齿 & （1 年） & 10本/日（15年） & - & & - \\
\hline 4 & 冠 & （ 5 年） & - & - & & - \\
\hline 5 & 圽菌 & （10年） & 30本/日 （45年） & - & & - \\
\hline 6 & & & 60本/日（45年） & - & & - \\
\hline 7 & & & 40本/日（40年） & - & & - \\
\hline 8 & & & 40本/日（45年） & 癌腫一白板症 & BLM** $\rightarrow$ 切除 & - 局化 ${ }^{* * *}$ ( 7 年前) \\
\hline 9 & 茵牙 & 側㑯斜） & - & 乳頭尰 - 白板症 & 切除・局化*** & ( 6 年前) \\
\hline 10 & 義歯 & （8 年） & - & 白板症 & 切除 & ( 3 年 6 か月前) \\
\hline 11 & 義歯 & （10年） & - & 癌尰 & Rn $10,000 \mathrm{R}$ & ( 2 年前) \\
\hline
\end{tabular}

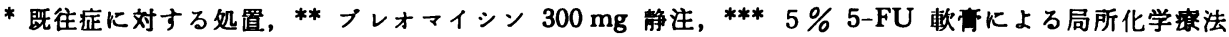

表 3 臨床型と部位

\begin{tabular}{|c|c|c|c|c|c|c|}
\hline 盬床型 & 部位 & 舌 & 軟口蓋 & 口底 & 畨肉 & 計 \\
\hline 紅 & 斑 & 3 & 2 & 1 & 1 & 7 \\
\hline 白 斑 紅 & 斑 & 2 & & & & 2 \\
\hline 白 & 斑 & 1 & & & 1 & 2 \\
\hline 計 & & 6 & 2 & 1 & 2 & 11 \\
\hline
\end{tabular}

瞭であり, 白斑紅斑混在型の 2 例と紅斑型の 1 例は不明 瞭であった（表 2-a）.

硬さは, 白斑型の 1 例がやや硬かったほかは, 全例周 用健常粘膜と差を認めず，軟らかかった（表 2-a）。 ま た，硬結は全例触知されなかった。
表 4 臨床型と大きさ

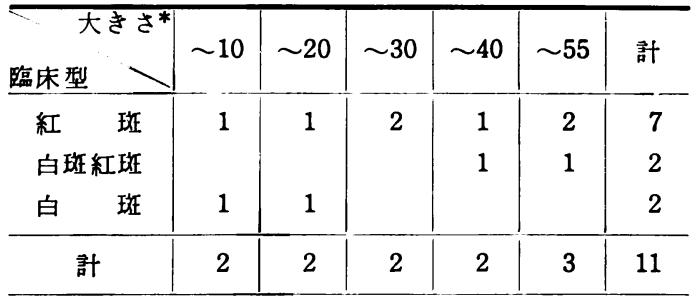

* 単位 $\mathrm{mm}$

疼痛については, 白斑型の 1 例を除き, 全例刺激痛を 認めた（表 2-a ）. 刺激痛の種類は義歯などの歯科的刺 激因子によるもの 7 例, 香辛料などの食事によるむの 3 例であった。 


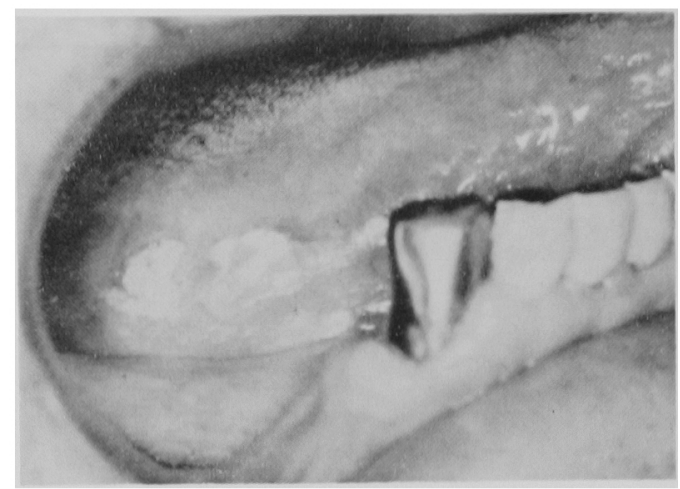

图 1-a 症例 1 74菠紧性:

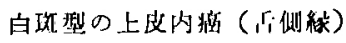

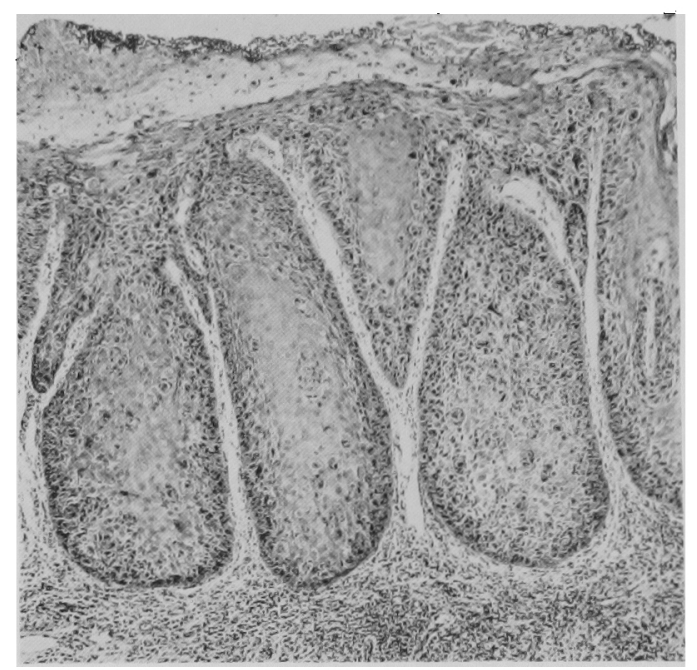

图 1-b 症例 1 の組織所見

上皮内癌 $(\mathrm{H}-\mathrm{E}$ 染色, $\times 52)$

表 5 初発症状より診断確定むでの期問

\begin{tabular}{|c|c|c|c|c|c|c|c|}
\hline 臨床 & & $\widetilde{\sim}$ 出月 & $\widetilde{6}$ 加月 & $\sim 1$ 作 & ～ 2 年 & ～ 5 年 & 計 \\
\hline 紅 & 斑 & \multirow[t]{3}{*}{2} & \multirow{3}{*}{ 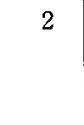 } & 1 & \multirow[t]{2}{*}{2} & \multirow{3}{*}{1} & \multirow{3}{*}{$\begin{array}{l}7 \\
2 \\
2\end{array}$} \\
\hline \multicolumn{2}{|c|}{ 白斑紅斑 } & & & 1 & & & \\
\hline 白 & 斑 & & & 1 & 1 & & \\
\hline \multicolumn{2}{|c|}{ 計 } & 2 & 2 & 3 & 3 & 1 & 11 \\
\hline
\end{tabular}

4. 初発症状および診断確定までの期間（表 2-a , 5)

初発症状としては刺激痛が10例と多く，粗造感（白斑 型，歯肉）は1例であった。

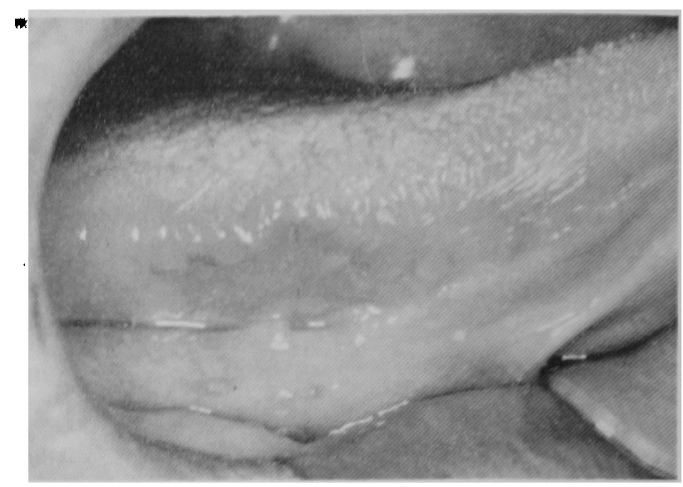

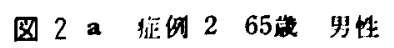

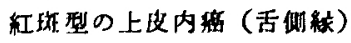

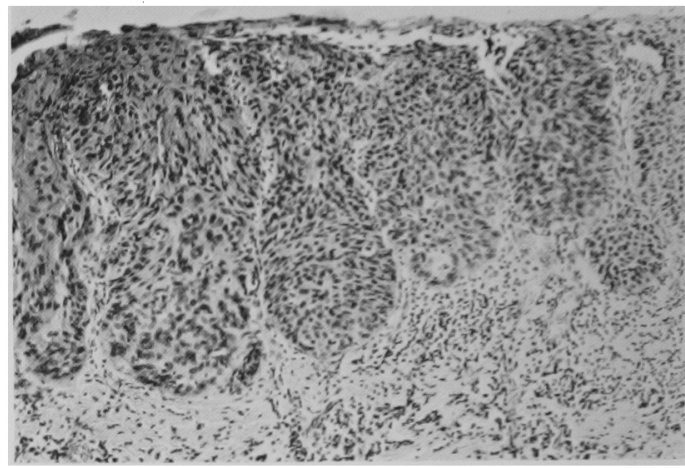

图 2-b 症俳 2 の組所胃 上皮内留 $(\mathrm{H}-\mathrm{E}$ 染色, $\times 8 \overline{5})$

表 6

\begin{tabular}{|c|c|c|c|c|c|c|}
\hline 臨 & 床 开 & 型 & 例 数 & 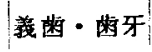 & 盎 & 煙 \\
\hline 紅 & & 斑 & 7 & 4 & & 4 \\
\hline 白 & 斑 紅 & 斑 & 2 & 2 & & \\
\hline 白 & & 斑 & 2 & 2 & & 1 \\
\hline \multicolumn{3}{|c|}{ 計 } & 11 & 8 & & 5 \\
\hline
\end{tabular}

症状に気づいてから上皮内癌と診断されるまでの期間 は 3 週〜 5 年であった。

臨休型と期間との関連については, 紅斑型は 6 か月以 下の短期間のものが多かったが，白斑紅斑混在型と白斑 型は全例 6 か月越えていた（表 5).

5. 质因（表 2-b，6）

本症11例中，蔽牙や義歯などの歯科的刺激因子の認め られたものは 8 例，また中等度以上の契厔習慣（1日20 〜60本, $40 \sim 45$ 年間) は5 例に認められた。 


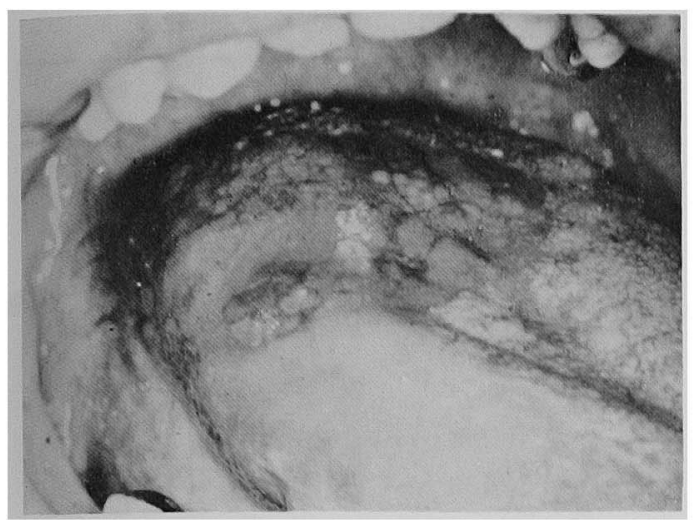

图 3-a 症例 3 29放 女性: 紅斑型の上皮内癌（舌背〜側䋹）

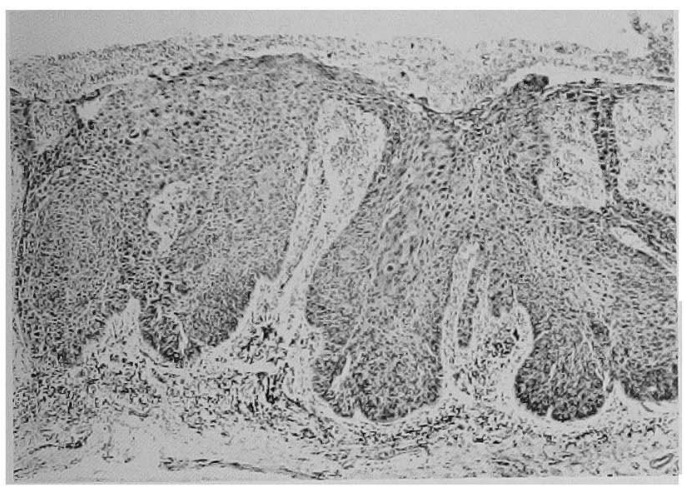

图 3-b 症例 3 の組織所見 上皮内瘦 (H-E 染色, $\times 42)$

臨床型別には，紅斑型では菡科的刺激因子々知煙が 4 例ずつ同数であったが，白斑紅斑混在型と白斑型は歯科 的刺激因子が多く認められた（表 6).

部位別には，舌では雪科的刺激因子が多く，軟口蓋の 2 例性契垤との関連が疑われた。

\section{6. 関連疾患（表 2-b）}

対象症例中，口腔内の関連する既往疾患は，癌腫之白 板症 1 例, 癌腫 1 例, 白板症之乳頭腫 1 例, 白板症 1 例 の計 4 例であった，その内訳は，症例 8 では，7年前下 影俻肉口底移行部の扁平上皮癌に対し，ブレオマイシン $300 \mathrm{mg}$ を静注し, 腫煌が治瘡して白板症となったため, 切除を行った。 まむなく、白板症が再発したため，5\% 5-FU 軟高を染布し，白板症は消失した，症例11では，口 底の扁平上皮癌に対して，2 年前に Rn seed $(10,000 R)$ を刺入し，腫陽は消失した，症例 9 では， 6 年前に舌側縁 の乳頭尰を切除し，白板症に対しては生検を行った，そ の後, 病変の悪化が疑われたので, 2 回にわたり 5-FU 顿管染布を行って, 白板症は消失した，症例10では 3 年

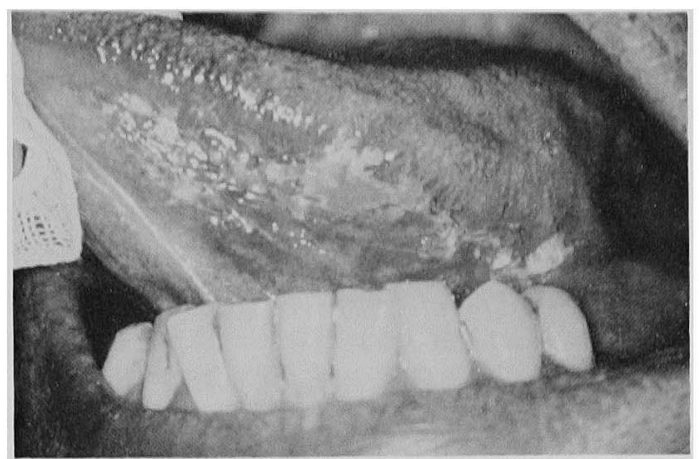

因 4-a 症例 4 35跑 男性

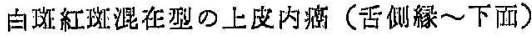

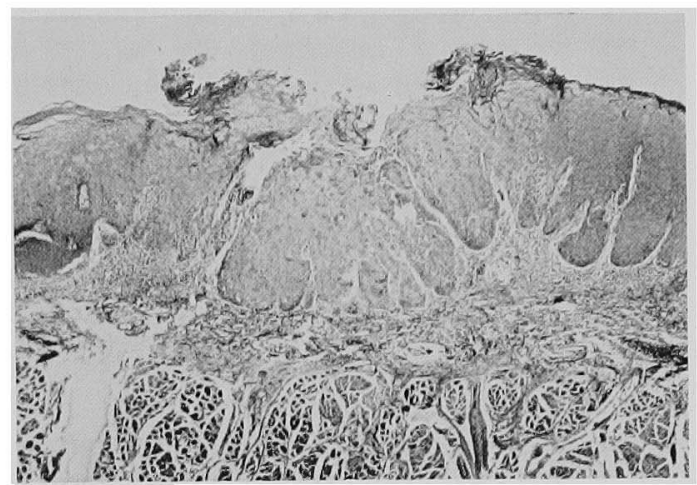

図 4-b 症例 4の組織所見 白板症病変の一部に上皮内癌像を認め方 (H-E 染色, $\times 24$ )

6 か月前に白板症の切除（舌部分切除）を行っている。 その泳か, 臨床的には他臟器の尰谤および前癌性病变 などの合伊や既往は認められなかった。

\section{IV. 治 療 成 績}

\section{1. 一次治療成績（表 7 11）}

口腔粘膜上皮内癌11例に刘する一次治療法は，切除 4 例, 渲結外科 1 例，放射線療法 3 例，放射線化学併用療 法 1 例, 化学潦法（治療に応じないため）1例, 刺湤除 去 1 例であった。これら症例の観察期間は 1 年 2 か月〜 12年 8 か月, 平均 3 年11か月であった。

一次治療成績を再発の有無で検討したところ，表 8 の ごとく，倲結外科を含さ外科療法群では 5 例中 1 例に白 板症が発症したが，癌の再発はなかった，放射線療法群 (化学療法併用を含む) では 4 例中 3 例に再発がみられ， いずれも浸潤癌と䛦断された，その他の 2 例（化学療法 之刺激除去）は，それぞれ 6 か月後と 2 年10か月後にい 


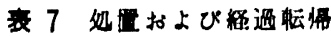

\begin{tabular}{|c|c|c|c|c|c|c|}
\hline 症例 & 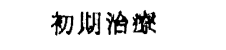 & 綘进（比润） & 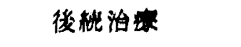 & 忶 & 龦 & 地间 \\
\hline 1 & 放 ( $\mathrm{Ra} 7,500 \mathrm{R})$ & 再発想し & - & 生 & 存 & 1 年 2 か月 \\
\hline 2 & 切除 & 再発䄻し & - & 生 & 祥 & 5 年 1 か月 \\
\hline 3 & 制湤除去 & 浸澖瘃（2 年10か月） & 故 ( $(\mathrm{Rn} 10,000 \mathrm{R})$ & 死 & $\leftarrow$ & 12年 8 か月 \\
\hline 4 & 切除 & 再登航し & - & 生 & 存 & 4 年 1 只月 \\
\hline 5 & 切除 & 再発然し & - & 生 & 存 & 4 年 4 か月 \\
\hline 6 & 化・故 (*1) & 再笞（1 年 4 か月） & 外 (*2) & 死 & ᄃ & 4 年 1 か月 \\
\hline 7 & 放 (*3) & 再発（10か月） & 放·外·化（*4） & 死 & $亡$ & 3 年 1 か月 \\
\hline 8 & 切除 & 再器低し & - & 生 & 存 & 2 年10か月 \\
\hline 9 & 杪綃外科 & 央発然し & 一 & 生 & 存 & 2 年 1 か月 \\
\hline 10 & 故 (Au 8, 400R) & 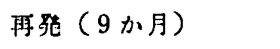 & 外 $(* 5)$ & 生 & 存 & 2 年 1 か月 \\
\hline 11 & 化 $(* 6)$ & 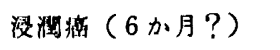 & 化（*6） & 死 & 亡 & 1 年 3 か月 \\
\hline
\end{tabular}

*1 ブレオ $105 \mathrm{mg} \rightarrow{ }^{60} \mathrm{Co} 5,000 \mathrm{rad} \rightarrow{ }^{198} \mathrm{Au}$ grain $4,500 \mathrm{R}$

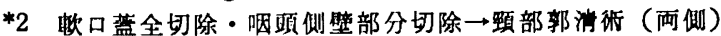

*3 ${ }^{60} \mathrm{Co} 3,000 \mathrm{rad} \rightarrow{ }^{188} \mathrm{Au}$ grain $7,300 \mathrm{R} \rightarrow$ 電子線 4,000+3,000 rad

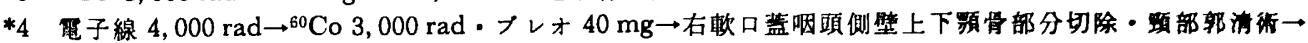
${ }^{60} \mathrm{Co} 4,000 \mathrm{rad} \rightarrow$ 化 (FT-207, プレオ, PS-K)

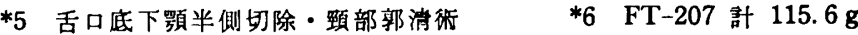

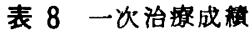

\begin{tabular}{|c|c|c|c|}
\hline 治療法 & 再発なし & 再発（浸潤癌） & 計（浸潤㾞） \\
\hline 科 & $5^{*}$ & & 5 \\
\hline 放 射線 & 1 & $3 \quad(3)$ & $4(3)$ \\
\hline その他 & & $2^{* *}(2)$ & $2(2)$ \\
\hline 計 & 6 & $5 \quad(5)$ & $11(5)$ \\
\hline
\end{tabular}

*1例に白斑（異型上皮）の発症あり,**縮小せず

表 9 臨床型と一次治療成樍

\begin{tabular}{|c|c|c|c|}
\hline 臨床型 & 再発なし & 再発*(浸潤癌) & 計（浸潤瘦） \\
\hline 斑 & 3 & $4(4)$ & $7(4)$ \\
\hline 白斑紅斑 & 1 & $1(1)$ & $2(1)$ \\
\hline 白 斑 & 2 & & 2 \\
\hline 計 & 6 & $5(5)$ & $11(5)$ \\
\hline
\end{tabular}

*縮小せずを含む

ずれも浸潤癌と診断された．本症全体では，11例中 5 例 (45\%) に浸潤癌が確認された。

\section{臨床型と一次治療成績（表 9)}

臨床型別には紅斑型の 7 例中 4 例と, 白斑紅斑混在型 の 2 例中 1 例に, 浸潤癌が発症した。 なお，根治的処膡 の行えなかった 2 例（症 例 $3 ， 11$ ）を除くと, 9 例中 3 例 $(33 \%)$ が再発，浸潤癌と診断された。 また臨床型別 には紅斑型の 6 例中 3 例 $(50 \%)$ に再発（浸潤癌）が生

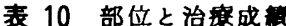

\begin{tabular}{|c|c|c|c|}
\hline 部 位 & 再発なし & 再発*（漫洞富） & 計（浸䦨㻤） \\
\hline 舌 & 4 & $2(2)$ & $6(2)$ \\
\hline 軟 口盖 & & $2(2)$ & $2(2)$ \\
\hline 口底 & & $1(1)$ & $1(1)$ \\
\hline \multirow[t]{2}{*}{ 宷 } & 2 & & 2 \\
\hline & 6 & $5(5)$ & $11(5)$ \\
\hline
\end{tabular}

*樎小せずを含む

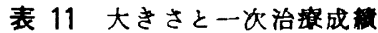

\begin{tabular}{|c|c|c|c|}
\hline 大きさ $(\mathrm{mm})$ & 再発なし & 再発*(浸潤虎) & 計（浸閏痹） \\
\hline$\sim 20$ & 4 & & 4 \\
\hline$\sim 40$ & 2 & $2(2)$ & $4(2)$ \\
\hline$\sim 50$ & & $3(3)$ & $3(3)$ \\
\hline 計 & 6 & $5(5)$ & $11(5)$ \\
\hline
\end{tabular}

*樎小せずを含む

じたことになり，他の臨床型では再発が認められなかっ た.

\section{部位と一次治療成精（表 10）}

部位別には軟口蓋では 2 例中 2 例に，口底では 1 例中 1 例に，また舌では 6 例中 2 例に浸潤癌が発症した。 な お，根治的処置の行えなかった 2 例を除くと，軟口蓋 ( 2 例中 2 例)，舌 ( 5 例中 1 例) の順に再発 (浸潤癌) 


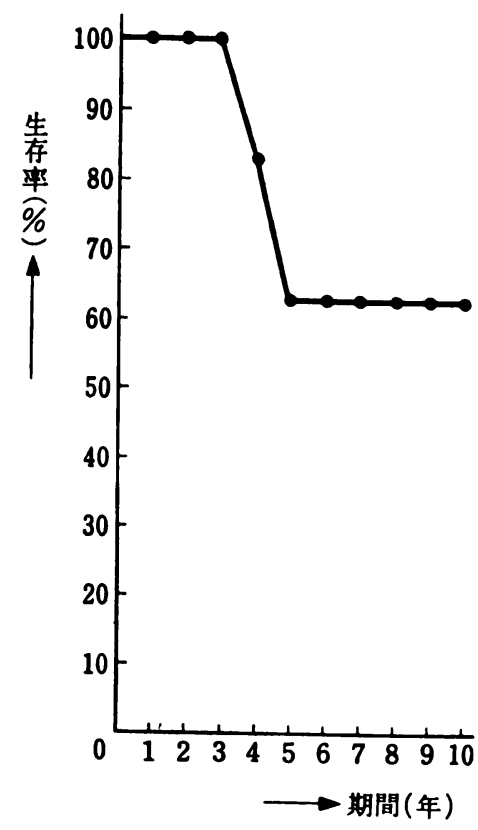

図 5 上皮内盘10例の果稳生存花

が多いことになり，来肉では再発は認められなかった。

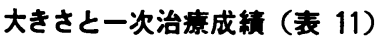

病変の大きさか： $41 \sim 55 \mathrm{~mm}$ では 3 例中 3 例に, 21 $40 \mathrm{~mm}$ では 4 例中 2 例に, 浸潤癌が発生し, $20 \mathrm{~mm}$ 以 下では浸潤癌の発生は認められなかった．根治的処瞋の 行えなかった 2 例を除くと，41〜 $55 \mathrm{~mm}$ では 2 例中 2 例に, 21 40 $\mathrm{mm}$ では3 例中 1 例に，それぞれ再発か; みられたことになり, 病変の大きなむの程, 再発傾向が 高く、浸潤癌の発症率が高い結果であった。

\section{2. 最終治虔成績}

\section{漫洲落吐症後の治療経過（表 7)}

浸润癌の確認された 5 例のその後の治療法は, 外科療 法 2 例（症例 6, 10)，放射線㞠法 1 例（泟例 3)，外科 放射線化学併用療法 1 例（症例 7 ), 化 学療法 1 例（正: 例11) であった。 これら 5 例の経過については，化学療 法の 1 例は，患者の治療拒否のため，積極的処直は行え ず， 1 年 3 か月後に死亡した．他の 4 例のらち 3 例（症 例 $3,6,7)$ は 3 年 1 か月〜 12 年 8 か月後に腫場死して おり，1例（症例10）は 2 年 1 か月後の現在, 再発なく 生存中である。

取俻治䔔成樍（表 7, 图 5)

本症11例の転帰は生存 7 例, 死亡 4 例であった. 積極 的な治療を行えなかった 1 例を除いた10例の累積生存率 は，3 年100\%，5 年, 10年 $62.5 \%$ （標準誤差 $21.4 \%$ ） であった.

\section{V. 考察}

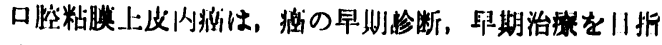

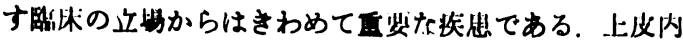

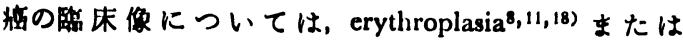
crythroplakia(18), Bowen 病14 18). 一部 leukoplakia ${ }^{17 \sim 1 \theta)}$ なとの報告があるが，上皮队胝をまとめての研究報告は

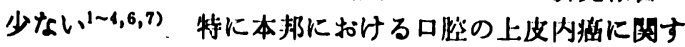
ろ報告はほとんどみられない7,20,21) 以下，门験例を山 心に，口陾の上皮内謏について愉討を行った。

A. 臨床所見について

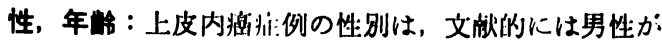
女性の約 2 倍程度と多かったが ${ }^{1,2)}$ ，自験 例では男性 6 例，女性 5 例とあまり差を認めていない，年龄について は Shafer (1975)1)によれば，50歳代をピークとし，40 ～70歳代に多いとされており，自榆例は60歳代にピーク を有している点が異なるものの, 高制者に多い点には変 わりはない.これら性差, 年路分布については上皮内烟 を癌の早期病変とすることに矛盾を示するのではなかっ たか，上皮内瘦症例が浸潤癌症例よりも若いという傾向 は必ずしも認められなかった。

部 位: 発症部位については, Shafer は 82 例中, 口 低 $(23 \%)$, 舌 $(22 \%)$ ，口唇 $(20 \%)$ に多かったとして いる1，また, Shedd (1963)2) は10例收，口底 (50\%) と口峡部 (40\%) が多かったと報告している。一方，自 験例では舌 (55\%), 軟口蓋, 歯肉, 几底の順であった。 これら部位別頻度の相連は, 種々の要因によるであろら か，後述するごとく，人種や㖰慣などの相遣に基つくくも のが多いと考えられ，興味がもたれる.

臨床像：上皮队澏の 臨休像については, Mashberg ら $(1973)^{3)}$ は無症状の早期口腔扁平上皮瘦を報告し，その 中で.上皮内店46例について，紅斑性要素は93.5\%，白斑 性要素は72\%で，紅斑性要素が瘦の最も初期の可視的徵 候であると強調している。これに対し，Shafer は77名 82 病変の口腔上皮内癌を 6 型に分類し，その5ち白斑 (45.1\%) が最も多く，ついで紅斑 (15.9\%)，渞陽の順 であり, 白斑性要素 (58.5\%) の方が紅斑性要素 (25.6 \%)よりも多かったと報告している1） Shear らは10例 中紅斑 3 例，白斑紅斑混在 3 例，白斑 3 例， ほとんと変 化なし 1 例と報告し，白斑性要素と紅斑性要素に差を認 めていない2また， Shear (1972)4）も21例中臨床像の 明らかなむのでは, 顆粒状紅斑 (granular erythroplakia） 5 例, 白斑 4 例, 白斑紅斑混在 2 例, 潰汮 2 例, 腫脹 1 例と報告している. 自験例は紅斑が全体の64 \%を占め，白斑紅斑混在と白斑が少なく，Mashberg ら の報告3) に近いるのと考えられた，以上，報告者によっ て頻度は異なるるのの, 臨床像については, その分類の 主体が紅斑, 白斑, 白斑紅斑混在の 3 型であり, この 3 


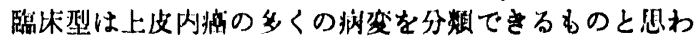
れた，また，後述するごとく，この 3 型は予後との相関

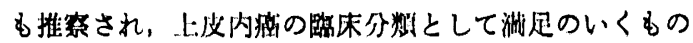
と思われた。

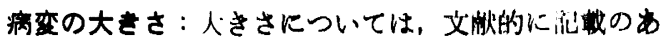
るものは少ないが, Mashberg らは46例中 $20 \mathrm{~mm}$ 米满 が全体の 78\%を占め, $30 \mathrm{~mm}$ を站光るものは $2 \%$ の であったとしている゙．これに対し，自検例では影小5

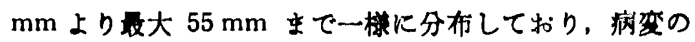

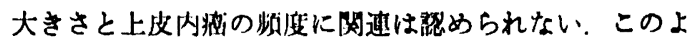

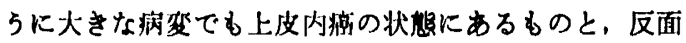
小さくとも下方への海洞の著しい惯とがあるが，これら 两者の相蚞はどのような理由によるのか, きわめて與味 のむたれるところである。

臨床型と大きさとの咸連では，白斑型は小さく，白斑 和斑混在型は大きく，紅斑型は小さなるのから大きなる のまでみられているか，これは上皮内癌発生過程が臨比 型により異なっていることを示唆するものであろら．

境 界: 病変の境界については, 白斑紅斑混在型は不 明膫であったが, 白斑型, 紅斑型ではその汪とんどが明 瞭であった。しかし, 治療にあたっては, field cancerization を示す多発性病変むあるとされているので21, 22)，治療範囲の決定には慎重を要する。

硬 結：硬結については，文献的にも ${ }^{3)}$, 自験例も。 まったく認められす，硬結を有する浸潤淈との鑑別には 役立つ. しかし，早期浸潤癌でも硬結をまったく触知さ れないるのが，60\%に琹められるので10)，雨者を鑑別す ることは必ずしも容易でない.

初唚症状：本症の症状については, 文献的には症状に そしく，また，症状がってもその頻度は低いとされ， 初発症状の記載は少ない(1 3). しかし, 上皮内癌はびら んや紅斑が多いことを考兄れば2 は)，なんらかの疼痛が 認められても不思議ではない，事実, 自験例では11例中 10例に刺激痛を認めており，すへての患者は症状を自覚 していた，なお，これら症状は生検時あるいは手術時も まったく同様に珰められており，刺激痛を有する持続性 の紅斑性病変は，特に精査が必要と考之られた。

初発症状より診断までの期間：Shaferによれば，期間 の明らかなものでは， 6 か月末満か7 $70 \%$ を占め， 1 年以 上は15\%のみであったとしている゙，自験例はやや期間 が長かったが，それでも 1 年末満が全体の64\%であり， 同様の傾向と考えられた。な拉，これら期間は浸潤癌症

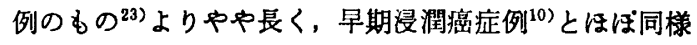
であった。

\section{B. 経過および治療成績について}

口腔上皮内癌の自然経過および治療成績をまとめて検 討した報告は，著者らが娭索した限りでは見い出せなか った．そこで症例報告を検討してみると，不治療で 3 年 間, 浸潤癌に進行しないるの 2 , 2 回の切除飞るかかわ

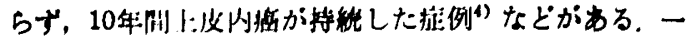

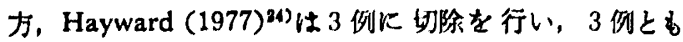

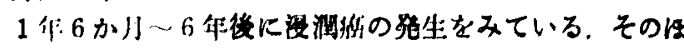

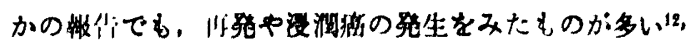

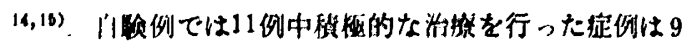
例で，そのらち 3 例は 9 か月〜 1 年 4 か月後に再発し,

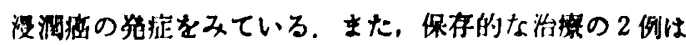

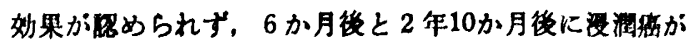
確烈されている。自矣例全体では11例中 5 例，45\%か：

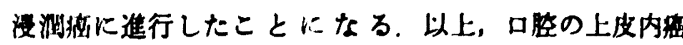

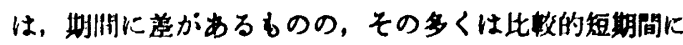

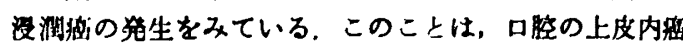

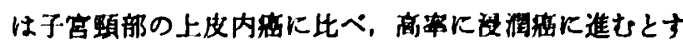

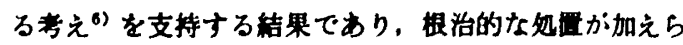
れなければ，上皮内船は，期間の差こそあれ，汪 100 \%没洞活に進行するであろらと考えられた。

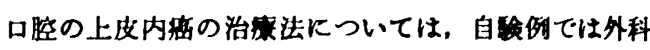

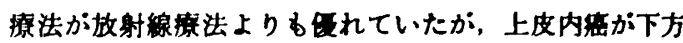
への浸洞を欠くことを考えれば，当然の結果とるいえよ 5。しかし，部位や大きさによっては必ずしも切除する ことは容易でなく，また機能保存の面からす問題が残 る.このような症例に対しては，凍結外科がきわ有 効な手段と考元られ，自検例の 1 例む凍結外科を応用 し，好結果を得ている ${ }^{26)}$.

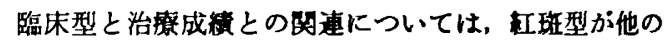

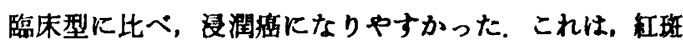
型では組械学的に病変全体が上皮内緮の像を示し，しか も大きな病変が多いためと考えられる。

部位と治療成結との関連については，敕口蓋，ついで 舌の順に再発，漫润癌の発症が多かったか，これは㪀口 蓋病変が舌に比べ治療しにくいためと推察される.

大きさと治療成綨との関連については，大きないの程 再発しやすく，漫洞艘を発症しやすかったのは当然のこ とと思われるが，特に病変の大きさが $40 \mathrm{~mm}$ を越える ののでは，浸洞癌と同様に报う必要があるかもしれな い.

口腔上皮内癌の最終治療成精については，終始，積㮩 的な治療を行い得なかった 1 例を除く，自験例10例の累 積生存率は 3 年 $100 \%, 5$ 年, 10 年 $62.5 \%$ であった。 こ の治療成綪は，われわれがすでに発表した口腔の早期浸

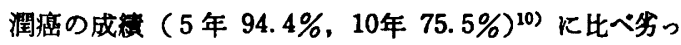
ていた，この理由としては，例数が少なく，钼察期間が 短い例が多いこと，病変の大きなるのが多かったことな どがあげられる，しかし，この治療成樍に直接影每を与 えているのは, 再発し, 漫潤癌の生した症例の予後が不 良であったことによるものであり，上皮内泊から生じた 浸潤癌は他の浸鬫癌に比へ，悪性度が高いのか，あるい は癌治療としては二次症例であるためか，今後検討を要 する，いずれにせよ，口腔上皮内癌の治療法としては， 
浸洞癌を生じる以前に，稓極的，根治的な処温が必要て あることを示す結果であった。

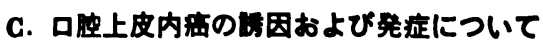

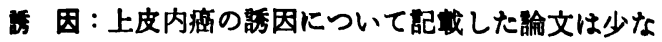
いが, Shedd によれば 10 例全例が 中等度以上の䒜䙳習 貫を有し，また，6例は大酒家で，5ち3 例は肺硬変に 䍜患していたとされている゙．自会例では大酒家はいな かったが，中等度以上の泽煙者が 5 例みられた。なお，

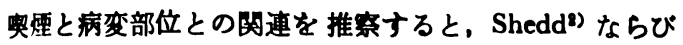
に自検例では奥㖶者の䄪半数は口峡部に病変を有してい

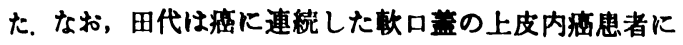

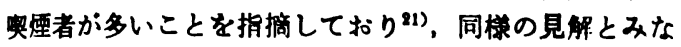
せよ5.

踩科的刺制因子については，文献的には，Woodbridge

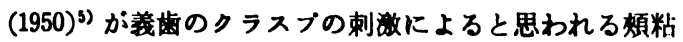
獏の上皮内癌 1 例をあげている。同硂例では11例中 8 例 に関連が聚われた。 なお，齿科的刺制因子は，部位では 舌病変のすのに, 臨床型では白斑を有する病変（白斑型 と白斑杠斑混在型）に関連が深いと考えられた。

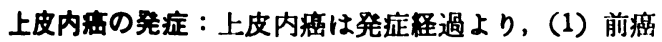

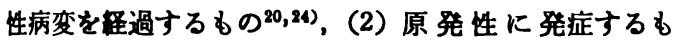
の，(3) 癌の周辺あるいは離れて多発性に発症するる の20-22) などに分けられる.ささらに，(4) 癌治療後に再 発性に生じた例の報告むある ${ }^{25)}$. 組樴学的に上皮内癌の 像を示すこれら病変を同一飞論ずることは無理かもしれ ないか，癌の発生を考える上では，きわめて興味のある 閣題である。自検例では（3）を対象から除外してお り，11例中，(1) 前癌性病変からと推察されるむのは 4 例，(2) 原発性と考えられるすのは 5 例，(4) 瘦の再発 と考えられるるのは 2 例であった。 自験例からは，原発 性の上皮内癌と前癌性病変からの上皮内癌とで, その性 状および経過に違いが筑われたが，例数が少なく，今後 の検討を要する。

\section{D. 上皮内萿の診断基準}

上皮内癌の診断は病理学者によっても, 必ずしも一致 をみないことが多いとされている6,27). 今回報告の上皮 内癌の詥断基準は, 異型細胞が上皮のほぼ全層にわたっ ており，しかも粘膜下層への浸潤のないるのとしたか， この基準を支持するるのは多い, 2, 1). しかし，このよう な敞しい上皮内癌の基準を，本来角化の認められる口腔 上皮にあてはめることは問題が多いとする報告すあ る6) また，WHO の口腔前癌病変に関する調查委員会 は，高度異型上皮と上皮内癌とは鑑別しにくく，経過に ついても差を認めにくく，両者を区別する利点は少ない

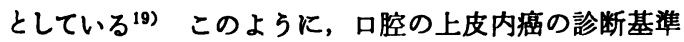
は、現在必ずしも一致をみておらず,ささらに臨床病理学 的な検討が望まれる。

\section{VI. 枯}

昭和39年より54年までの16年阔に，当科で口些粘膜上 皮内痁之䉼された11例について愉时を加之，以下の結 果を得た。

\section{1. 蕰床的索项}

㭧者の性別は男性 6 侧，女性 5 例で，年峆は29藏より

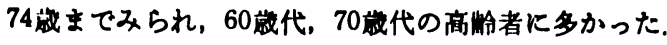

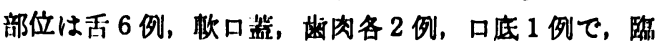

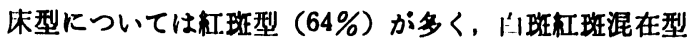
と白斑型むみられた。な拉，紅斑型は，莎，杴口蓋に多 く，白敏紅斑混在型は舌のみにみられた。病変の大きさ は 5〜55 mm に広く分布し，臨床型と大きさとの関連で は，紅斑型と白斑紅斑混在型は大きく，白斑型は小さい 傾向を示し，部位では軟口蓋と舌で大きく，海肉では小 さい傾向であった。

病变の境界は明膫なものが多く，臨床型別には紅斑型 と白斑型は明瞭，白斑紅斑混在型は不明瞭であった。硬 さは柔軟で，硬結を触れたものはなく，刺制痛を有する 患者が忹とんどであった。

初発症状は粗造感の 1 例を除き，他はすへて刺做痛 で, 症状発症より部断までの期間は汪とんどが 2 年以下 で比較的短期間であった，誘因については，㓶煙と，齿 科的刺激が認められ，职口蓋では喫煙か，舌では歯科的 刺微因子か大き関与していると推察された。

上皮内癌の発症については，前癌性病変より生したも の 4 例，原発性のむの 5 例，癌治療後に再発性に生した むの 2 例で，これら三者間に違いがみられるか否か, 明 らかにし得なかった.

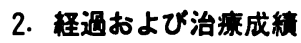

上皮内癌11例中，積極的な処固を受けたものは 9 例 で, らち 3 例は再発（浸潤癌）が浔められた。棈極的な 処置を受けなかった他の 2 例は後に浸洞痁が発症してお り，上皮内癌全体では11例中 5 例 $(45 \%)$ に浸潤癌か確 認された。 上皮内癌診断より浸潤癌発症までの期閒は 6 か月〜 2 年10か月（平均 1 年 3 か月）と短期間であっ た。これら結果は口腔の上皮内癌が子宮頸部の上皮内癌 に比べ，高率に，また短期間に浸潤㿋に進展することを 示していた。

上皮内癌の治療成績は，外科療法が放射線療法よりも 優れていた，しかし，大きな病変に対する外科的切除は 機能および形態保存に問題があるため，厷範囲な上皮内 癌に対しては凍結外科がきわめて有効な治療法であると 考えられた。

上皮内癌症例の経過転帰は，生存 7 例，死亡 4 例であ った．釉始，積極的な処置を行い得なかった 1 例を除 き, 上皮内癌 10 例の累積生存率は，3 年 $100 \% ， 5$ 年， 10年62.5\%であり，良好な成績とはいい難かった。 その 
理由については，上皮内癌病变が大きかったこと，対橡 例数が少なく，微然期閒が知期阔のものが多かったこと などが考党られるがささらに梌村を烦する。

本踚文の要旨の一部は，1979年 4 月 4 日第33回日本口 腔科学会総会に打いて器祳した。

本研究の一部は1979年お゚び1980年厚生省がん研究助 成金比った。

\section{引 用 文 献}

1) Shafer, W.G.: Oral carcinoma in situ. Oral Surg 39: 2271975.

2) Shedd, D.P., Hukill, P.B., Klingerman, M.M., Gowen, G. F.: A clinicopathologic study of oral carcinoma in situ. Am J Surg 106: 791 1963.

3) Mashberg, A., Morrissey, J.B., Garfinkel, L.: A study of the appearance of early asymptomatic oral squamous cell carcinoma. Cancer 32: 14361973.

4) Shear, M.: Erythroplakia of the mouth. Int Dent J 22: 4601972.

5) Woodbridge, H. McF: Carcinoma in situ: Diagnosis and study of a case. Oral Surg 3: 14471950.

6) Kramer, I.R.H.: Carcinoma-in-situ of the oral mucosa. Int Dent J 23: 941973.

7）太田邦夫：上皮内瘦あるいは Carcinoma in situ Кついて。医学のあゆみ 17: 2501954.

8）天笠光雄，增尾勝己，高木 実，他：口腔粘膜 紅色肥厚症の臨床病理学的研究. 日外誌 25: 5141979.

9) UICC: TNM-Classification of Malignant Tumours. ed 3, International Union Against Cancer, 1978.

10）天笠光雄, 横尾恵美子, 結城勝彦, 他 : 口腔粘 膜早期浸潤癌の臨床的研究. 日外誌 26:1497 1980.

11) 高木 実, 迫田由起子, 石川栖朗, 他 : 口腔粘 膜扁平上皮癌の病理組織学的研究一II 紅色肥 厚症について一。病誌 42: 3731975.

12) Williamson, J.J.: Erythroplasia of Queyrat of the buccal mucous membrane. Oral Surg 17: 3081964.

13) Shafer, W.G. and Waldron, C.A.: Erythroplakia of the oral cavity. Cancer 36: 1021
1975.

14) Gorlin, R.J.: Bowen's disease of the mucous membrane of the mouth. Oral Surg 3: 35 1950.

15) Hornstein, O., Pape, H.D.: Morbus Bowen der Mundschleimhaut. Dermatologica 131: 3251965.

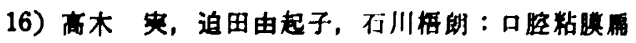
平上皮忽の的理組学的研究—I Bowen 样 病变について。不病誌 43: 131976.

17) Waldron, C.A. and Shafer, W.G.: Leukoplakia revised: A clinicopathologic study of 3256 oral leukoplakias. Cancer 36: 1386 1975.

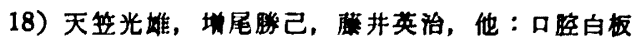

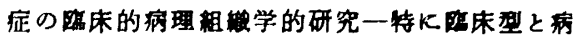

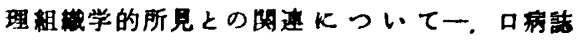
46: 30: 1979.

19) WHO Collaborating Center for Oral Precancerous Lesions: Definition of leukoplakia and related lesions: An aid to studies on oral precancer. Oral Surg 46: 5181978.

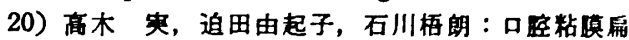

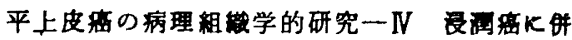
存してみられる上皮内船打上ひ異型上皮につい， て一。不病就 43: 211976.

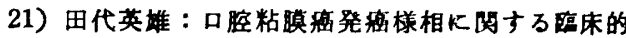
病理学的研究. 口科誌 22: 1761973.

22) Slaughter, D. P., Southwick, H. W. and Smejkal, W.: "Field cancerization" in oral stratified squamous epithelium: Clinical implications of multicentric origin. Cancer 6: 963 1953.

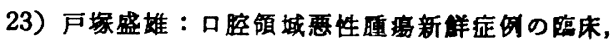
組掝怙上び稩胞学的研究. 口病誌 38: 941971.

24) Hayward, J.R. and Regezi, J.A.: Oral dysplasia and in situ carcinoma: Clinicopathologic correlations of eight patients. J Oral Surg 35: 7561977.

25) Rowe, N.H. and Wilson, A.E.: Carcinoma in situ in a patient with a history of malignancy: Report of case. J Oral Surg Anesth Hosp 20: 4421962.

26）堀越 勝, 力丸浩一, 曾田忠雄, 他: 東結外科 の口腔湎域への応用. 日外誌 25：1048 1979.

27) Kirkland, J.A.: Atypical epithelial changes in the uterine cervix. $J$ Clin Path 16: 150 1963. 